\title{
ТРЕВОЖНО-ДЕПРЕССИВНЫЕ РАССТРОЙСТВА У БОЛЬНЫХ САХАРНЫМ ДИАБЕТОМ 2 ТИПА И ИШЕМИЧЕСКОЙ БОЛЕЗНЬЮ СЕРДЦА
}

\author{
Ланкина М.С., Кудинов В.И., Пащенко Е.В, Коцкая А.В.
}

ФГБОУ ВО «Ростовский государственный медицинский университет» Минздрава России, Ростов-на-Дону

ЦЕЛЬ: оценка выраженности тревожно-депрессивных расстройств у больных сахарным диабетом 2 типа (СД-2) в сочетании с ишемической болезнью сердца (ИБС) и кардиоваскулярной автономной нейропатией (КАН).

МАТЕРИАЛЫ И МЕТОДЫ: обследовано 118 больнЫХ СД-2 и ИБС, находившихся на лечении с острым коронарным синдромом в ГБУ РО «Ростовская областная клиническая больница». 1-я группа - 42 пациента СД-2 в сочетании с ИБС, 2-я группа - 30 пациентов с СД-2 и ИБС, у которых диагностирована КАН, 3 группа - 46 больных с ИБС без нарушений углеводного обмена. Длительность СД-2 составляла $11,2 \pm 2,1$ лет. Средний возраст больных - 64,1 33,6 лет. Анализировались результаты холтеровского мониторирования ЭКГ, результаты коронарографии. Для оценки нарушений в эмоционально-волевой сфере была использована Госпитальная Шкала Тревоги и Депрессии (HADS).

РЕзУЛЬТАТЫ: в 1-й группе депрессивные расстройства диагностированы у 47\% больных. Средний

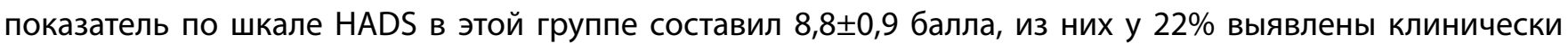
значимые депрессии. Тревожные расстройства у пациентов 1-й группы были выявлены у 59\% больных, средний балл составил 11,6士0,9 балла. По результатам коронарографии в этой группе преобладали пациенты с двухсосудистым поражением коронарных артерий, у 60\% гемодинамически значимые стенозы. Во 2 группе пациентов с КАН распространенность депрессивных расстройств оказалась достоверно выше и составила 78\% ( $<<0,05)$ случаев, показатель HADS оказался $12,6 \pm 1,2$ балла ( $<0,05)$, клинически значимые депрессии встречались у $42 \%(p<0,05)$. Тревожные расстройства у пациентов 2-й группы так-

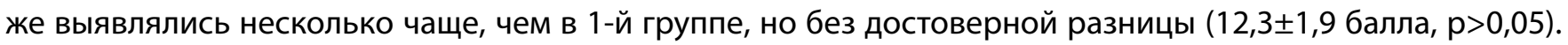
По результатам коронарографии во 2-й группе преобладало двух- и трехсосудистое поражение коронарных артерий. Реже тревожно-депрессивные расстройства встречались в 3-й группе пациентов с ИБС без нарушений углеводного обмена. Депрессивные расстройства диагностированы только у $28 \%$ пациентов




пы (p>0,05). Результаты коронарографии в 3-й группе носили наименее выраженный характер, преобладали пациенты с однососудистым поражением коронарного русла (74\%).

ВЫВОды: нарушения в эмоционально-волевой сфере у больных СД-2 в сочетании с ИБС могут выявляться более чем у 50\% больных, из них, при наличии СД-2, по сравнению с пациентами без нарушений углеводного обмена, преобладают депрессивные расстройства 47\% пациентов, а при наличии КАН их число возрастает до 78\%. У пациентов с депрессивными расстройствами преобладает многофокусное поражение коронарных артерий. 